\title{
Analysis of Korean Infertile Males by PDMS Microchip Gel Electrophoresis
}

\author{
Chungmu Kang, Seoungkwon Back. Byungok Choi, Suman Lee. ${ }^{\dagger}$ Kiwha Chung. ${ }^{\dagger}$ Seong Ho Kang." and Yongseong Kim"
}

\author{
Division of Natural Science, Kynngnam University, Masan 631-701, Korea. "E-mail: kimys@knangnam.ackr \\ ${ }^{\circ}$ College of Medicine, EWHA Womans University, Seotl 120-750, Korea \\ ${ }^{*}$ CHA Research Institute, Department of Urology, Department of Medicine CHA General Hospital, \\ Pochon CHA University, Seoul 135-181, Korea \\ ${ }^{\$}$ Department of Biological Science, Kongiu National University, Kongiu 314-701, Korea \\ ${ }^{"}$ Deparment of Chemistry, Chonbuk National Universiry, Jeoniu 561-756, Korea
}

Received November 15, 2005

Key Words : PDMS, Microchip, PEO, CAG, Infertile

Trinucleotide repeat expansion is a genetic disease related to abnormal increase of the repeat number of $(\mathrm{CGG})_{\mathrm{n}}$, $(\mathrm{CCG})_{\mathrm{m}},(\mathrm{CTG})_{\mathrm{n}},(\mathrm{GAA})_{\mathrm{m}}$, and $(\mathrm{CAG})_{\mathrm{m}} \cdot{ }^{1}$. Several diseases such as Fragile $\mathrm{X}$ syndrome, Huntington's disease $(\mathrm{HD}){ }^{2}$ Dentatorubral and Pallidoluysian atrophy (DRPLA), ${ }^{3}$ spinocerebellar ataxia type I (SCA I), ${ }^{4}$ and spinal bulbar muscular atrophy (SBMA) are known to be caused by trinucleotide repeat expansion. Among those diseases, SBMA produced muscular dystrophy, testicular atrophy, deficiency of androgen, and estrogen excess, and is known to cause male infertility. SBMA can be analyzed by diagnosis of CAG repeat number from male androgen receptor in chromosome Xq1112 exon $1 .^{6}$ Several countries including China. France, Japan, United States, and Germany have published many papers related to the characteristics of CAG repeat number distribution, however, only a few papers have been reported for infertility study in Korea?

For the measurement of $\mathrm{CAG}$ repeat number, conventionally slab gel electrophoresis (SGE) has been employed ${ }^{8,9}$ however, this method is known to be labor-intensive and time consuming. Especially, the sizing of DNA fragment is generally inaccurate in SGE (error usually more than $10 \%$ ), causing false determination of CAG repeat number. Microchip gel electrophoresis would be a good method of choice since it can reduce the analysis time and provide the high sensitivity with the potential for point-of-care diagnosis tool. ${ }^{10-15}$ Also, the error for size determination of the microchip gel electrophoresis could be less than that in SGE because the separation mechanism is based on capillary gel electrophoresis (error less than $2 \%$ ). ${ }^{16-19}$

Among many polymers used for microchip construction, ${ }^{20}$ poly(dimethylsiloxane) (PDMS) has shown many advantages. It has been widely applied for biomolecule analysis since the fabrication of PDMS is easy for nano- and microstructure and the optical transparency is excellent for UV/ VIS and fluorescence detection at $240-1100 \mathrm{~nm}$. Also, the production of the PDMS microchip is cost-effective without using harmful acids such as $\mathrm{H}_{2} \mathrm{SO}_{4}$ and $\mathrm{HF}$, and the chemical analysis is feasible under high electric fields. ${ }^{21-24}$

In this paper, Korean infertile males related to abnormal CAG repeat number in human genome Xq11-12 exon 1 were analyzed by using the PDMS microchip. The accurate CAG repeat number was measured by the microchip gel electrophoresis with $1.2 \%$ poly(ethylene oxide) and compared with data from conventional SGE. The PCR products for both the control $(n=50)$ and the infertile male patients $(n=$ 50 ) were analyzed by the microchip gel electrophoresis and their sizes were calculated by the independent sample t-test. For the control and the patients, it was confirmed that they were statistically significant $\left(\mathrm{P}^{2}=0.012\right)$ with $95 \%$ confidence level and the distribution pattern of CGA repeat number for the patients was unique compared to those from other countries.

Figure 1 shows the electropherograms of $\Phi \mathrm{X} 174 \mathrm{RF}$ DNA/Hae III fragments with various sieving matrices in 150 seconds. It was found that the optimized concentrations for each polymer solution were $1.0 \%$ methyl cellulose (MC), $1.2 \%$ 2-hydroxylethyl cellulose (HEC), 1.2\% hydroxylprop$\mathrm{yl}$ methyl cellulose (HPMC), and 1.2\% poly(ethylene oxide) (PEO). The numbers of theoretical plate for 234 bp were 8.8 $\times 10^{4}, 1.5 \times 10^{5}, 6.3 \times 10^{4}$, and $2.5 \times 10^{5}$ for MC, HEC, HPMC and PEO, respectively. Resolutions of the base pairs calculated between 271 bp and 281 bp were $1.8,1.4,1.9$, and 2.8 for MC, HEC, HPMC and PEO, respectively. Consecutive running was possible for less than 10 times with $\mathrm{MC}$, $\mathrm{HEC}$, and HPMC. However, more than 15 times of running was feasible with PEO for the same DNA sample.

The sizing of PCR product is important since CAG repeat number is related to SBMA. In order to ensure that the microchip gel electrophoresis can provide better sizing capability, the known size of 310 bp (from $\Phi X 174 \mathrm{RF}$ DNA/Hae III fragments) was mixed with $100 \mathrm{bp}$ ladder standard DNA and separated together in PDMS microchip as shown in Figure 2(a). Two calibration curves were tested to find more accurate value of the given DNA fragment. For example, the linear calibration curve (using 5 fragments of $100 \mathrm{bp}, 200 \mathrm{bp}, 300 \mathrm{bp}, 400 \mathrm{bp}$, and $500 \mathrm{bp}$ in $100 \mathrm{bp}$ DNA ladder) with $\mathrm{y}=0.256 \mathrm{x}+75.401$ for $310 \mathrm{bp}$ fragment produced $310 \pm 3$ bp (Figure 2(b)), while the exponential curve (all 11 fragments in 100 bp DNA ladder) with $y=$ $0.00008+0.00019 \mathrm{e}^{-\mathrm{x}: 217.68}$ generated $310 \pm 9$ bp (Figure 2 (c)). Here, y represents the migration time(s) and $\mathrm{x}$ stands 
(a)

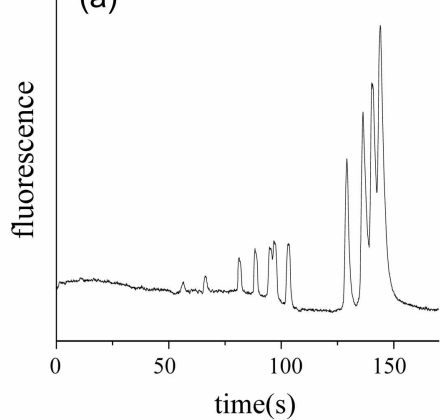

(b)

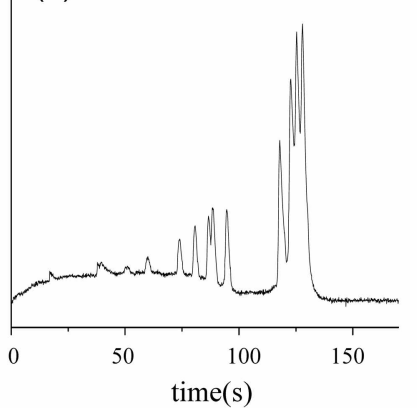

(c)

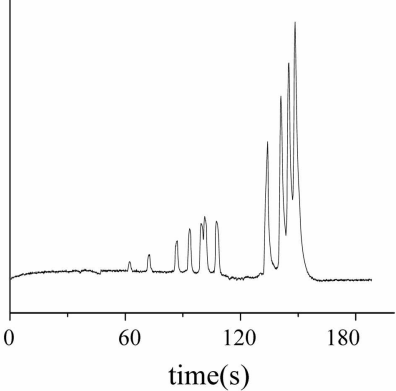

$(\mathrm{d})$

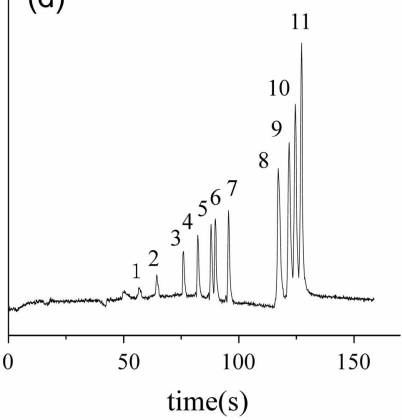

Figure 1. Flectropherograms of $\Phi$ X 174 RF [DNA/Hae III fragments with vatious polymer solutions. (a) $1.0 \%$ MC (b) $1.2 \%$ HEC (c) $1.2 \%$

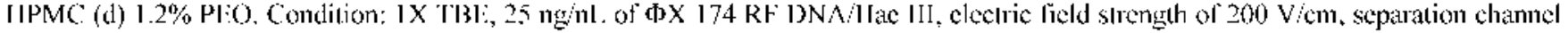
Iength of $40 \mathrm{~mm}$, channcl size; $80 \mathrm{tm}$ (width) $\times 50 / \mathrm{mm}$ (dcpth). Pcak assignment: I $-72 \mathrm{bp}, 2-118 \mathrm{bp}, 3-194 \mathrm{bp}, 4-234 \mathrm{bp}, 5-271 \mathrm{bp}$, $6-281$ bp, $7-310$ bp, $8-603$ bp, $9-872$ bp, $10-1073$ bp, $11-1358$ bp.

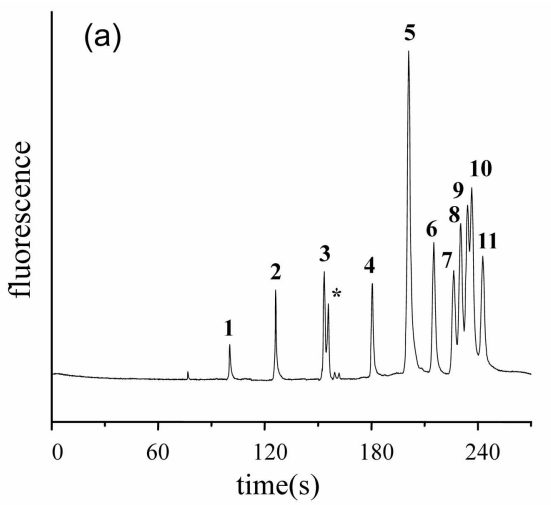

(b)

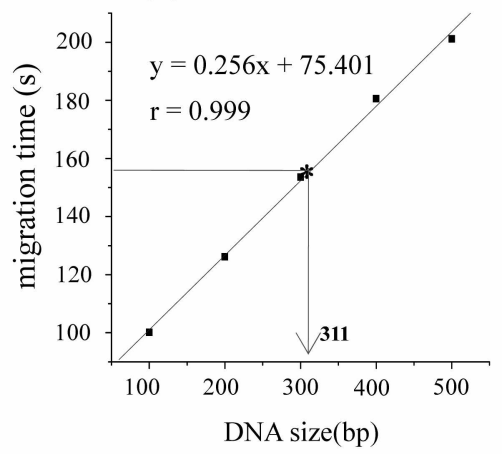

(c)

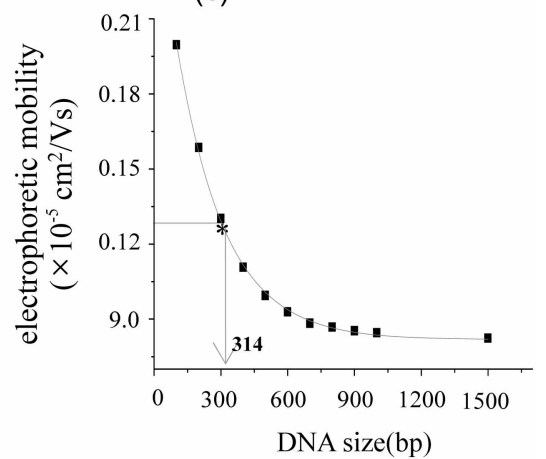

Figure 2. (a) Ilectropherogram of 100 bp [DNA standard ladder wilh 310 bp from $\Phi$ XX 174 RF DNA/ Iae III fragments, (b) a liner calibration curve using 5 DN $\wedge$ fragments ( $100 \mathrm{bp}, 200 \mathrm{bp}, 300 \mathrm{bp}, 400 \mathrm{bp}$, and $500 \mathrm{bp}$ ) from $100 \mathrm{bp}$ DNA standard ladder, and (c) a exponential curve using all 1 I fragments in 100 bp DNA ladder. Condition: $1.2 \%$ PEO, $130 \mathrm{ng} / / \mathrm{L}$ of 100 DNA ladder, $25 \mathrm{ng} / / \mathrm{L}$ of $310 \mathrm{bp}$ from $\Phi X 174 \mathrm{RF}$ DNA/Hae IIl fragments, other conditions as in Figure 1. Peak assignment: $1=100 \mathrm{bp}, 2=200 \mathrm{bp}, 3=300 \mathrm{bp}, 4=400 \mathrm{bp}, 5=500 \mathrm{bp}, 6=$ $600 \mathrm{bp}, 7=700 \mathrm{bp}, 8=800 \mathrm{bp}, 9=900 \mathrm{bp}, 10=1000 \mathrm{bp}, 11=1500 \mathrm{bp}, *=310 \mathrm{bp}$

for the [DNA size(bp). It turned out that the linear calibration curve provided more accurate size of the known [DNA fragment, therefore, it was used for the analysis of the PCR products of the control and the patients.

Table 1 shows the results of DNA fragment sizing by our microchip gel electrophoresis and conventional SGE. In SGE as shown in Figure 3, three sizes of DNA fragments ( 118 bp. 271 bp, and 310 bp from $\mathbf{\phi X} 174$ RF DNA/Hae III fragments) were determined by the linear regression curve with 100 bp DNA ladder. It is known that the size determined by SGE usually deviates from the real one with more than $10 \%$ error. $^{25}$ In Table 1 , it is clear that three different DNA fragments show the narrow error range of $1.0 \%$ to $4.2 \%$ with the microchip gel electrophoresis compared to that of $9.4 \%$ to $17.8 \%$ with the conventional SGE. Therefore, Table 1 confirms that the microchip gel electrophoresis should be the method of choice for the correct size determination of PCR products.

Figure 4 exhibits the example of the sizing of PCR product from one of Korean infertile males by the microchip gel electrophoresis. The linear curve $(y=0.218 x+65.509, r=$ 0.998 ) was constructed as the calibration curve employing 5
Table 1. INA fragment sizing by our microchip gel electrophoresis and the conventional SGE for $118 \mathrm{bp}, 27 \mathrm{l} \mathrm{bp}$, and $310 \mathrm{bp}$ from $\Phi$ X $174 \mathrm{RF}$ DNA/Hae Ill fragments

\begin{tabular}{cccccc}
\hline \multirow{2}{*}{ DNA size $(\mathrm{bp})$} & \multicolumn{2}{c}{ DNA Sizing $(\mathrm{bp})$} & & \multicolumn{2}{c}{ Error $(\%)$} \\
\cline { 2 - 3 } \cline { 5 - 6 } \cline { 5 - 6 } & MGE & \multicolumn{1}{c}{ SGE } & & MGE & SGE \\
\hline 118 & $120 \pm 3$ & $99 \pm 2$ & & 4.2 & 17.8 \\
271 & $273 \pm 3$ & $293 \pm 3$ & & 1.8 & 8.9 \\
310 & $312 \pm 3$ & $335 \pm 4$ & & 1.0 & 9.4 \\
\hline
\end{tabular}

fragments from 100 bp DNA standard ladder. The size of this PCR product was decided as $287 \mathrm{bp}$, meaning that $\mathrm{CAG}$ repeat number is close to 22 . A number of 222 bp was first subtracted from the size determined by the calibration curve since there are 222 bp non-CAG repeat region in the PCR product, then, the number was divided by 3 (C.AG bp).

For 50 control and 50 patient, their PCR products in the androgen receptor region related to infertility in male were all sized by the microchip gel electrophoresis. For each control and patient, the linear calibration curve was initially setup and used for the size determination. It was found that the average $C A G$ repeat numbers for the control and the 


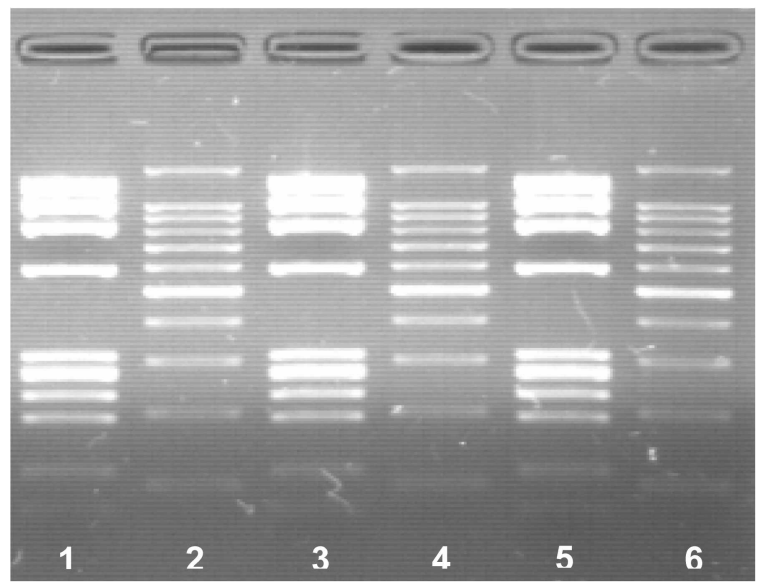

Figure 3. Slab gel electrophoresis (SGF) of 100 bp DNA ladder (lane 2, 4,6) and $\Phi \times 174 \mathrm{RF}$ ISNA/Hac III, Condilion: $1.5 \%$ agarose gel, $0.5 \times$ TBE, $2.0 / \mathrm{L}$ of $\Phi X 174 \mathrm{RF}$ DN $/$ / Iae III $(60 \mathrm{ng} /$ $\mu \mathrm{L}), 2.0 \mu \mathrm{L}$ of $100 \mathrm{bp}$ DNA ladder $(60 \mathrm{ng} / \mu \mathrm{L})$, the rumning voltage; $80 \mathrm{~V}$, the running time: $40 \mathrm{~min}$. the gel image instrument: Mupid+ $\alpha$.

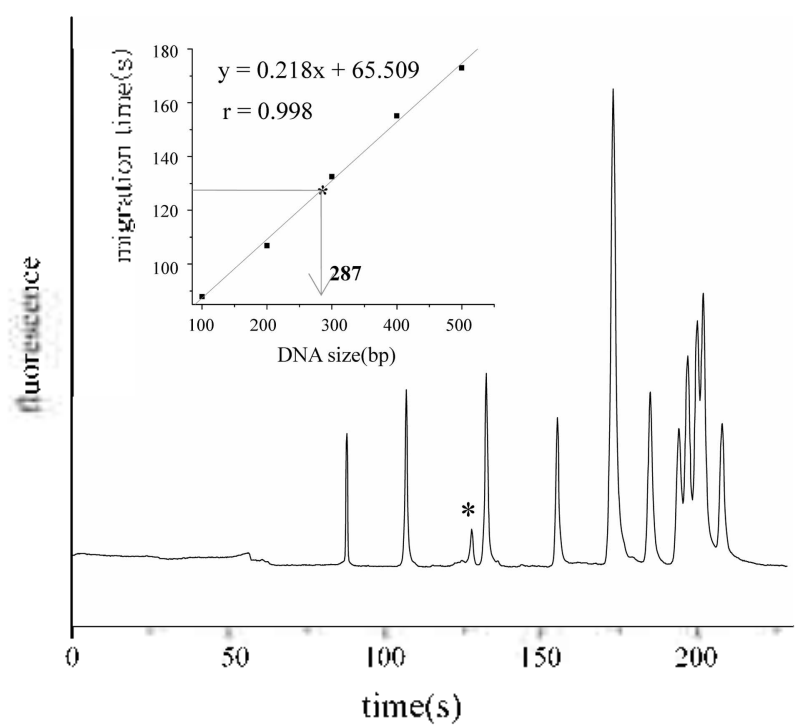

Figure 4. Electropherogram of the mixed sample; 100 bp DNA ladder and the PCR product (*, patient). Conditions the same as in Figure 2(a) except $3 \mu \mathrm{l}$ of the PCR product was added into $3 \mu \mathrm{l}$ of $130 \mathrm{ng} / \mu \mathrm{L}$ of I $100 \mathrm{bp}$ DNA ladder. The linear calibration curve is shown in the inset.

patients were $21.9 \pm 4.1$ and $23.1 \pm 2.9$, respectively. Although the average CAG repeat numbers for two groups were close, the distribution pattern for each group was different as shown in Figure 5. The statistical significance of two groups was investigated by the independent sample t-test. It turned out that the meaningful probability value ( $\mathrm{P}^{\mathrm{p}}$ ) was 0.012 . This value is less than 0.05 , implying that two groups are statistically different. The average C.AG repeat number for Korean infertile male is 1 higher than those from European and North American, and 1 less than that from Asian. ${ }^{7.26 .27}$ The range for $C . A G$ repeat number in Korean $(18-33)$ is higher than those from European (13-30) and North American (14-31).

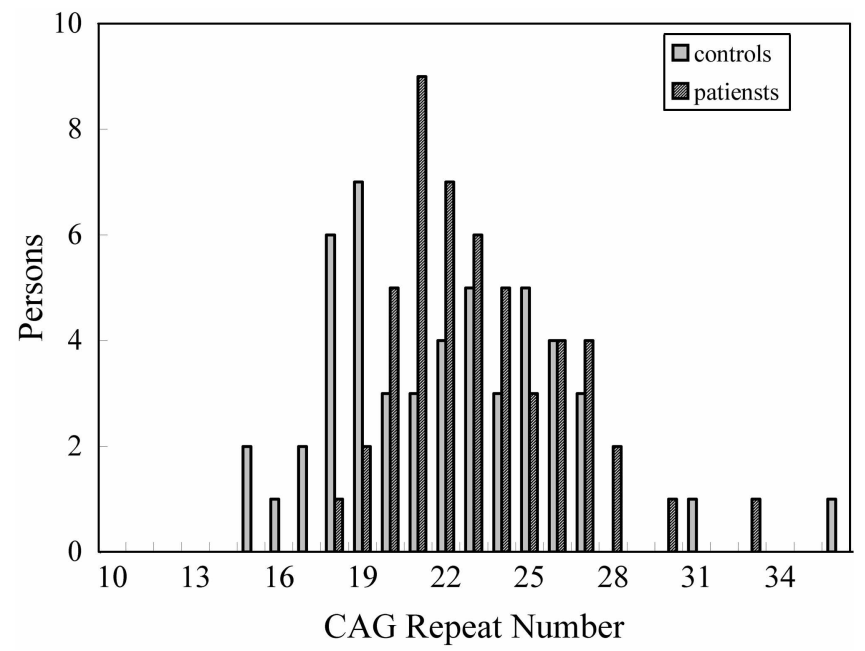

Figure 5. 1)istribution pattern of $C A \mathrm{G}$ repeal number of the control and the patient determined by the microchip gel electrophoresis.

From these data, we believe that the microchip gel electrophoresis would be the good method of choice for the SBMA diagnosis tool. Application of the microchip gel electrot phoresis for other discases related to stroke, Alyheimer, and vascular disease is under study.

\section{Experimental Section}

Chemicals. MC ( 2 wt. \% solution in $\mathrm{H}_{2} \mathrm{O}, 4000 \mathrm{cps}$ ), HEC (Mv ca. 1,300,000), HPMC ( $2 \%$ aqueous solution, 4000 cps), PTO (Mr $=8,000,000)$, (ris(hydroxymelhyl)-aminomethane, boric acid, elhylenediamineletraacetate (EDTA), and ethidium bromide (T.B) were purchased from Aldrich (Milwauke, WI, USA). A 100 bp DNA ladder (Takara Dio Inc., Japan) and $\Phi$ X 174 RF DNA/Hac ITI were also from Sigma-Aldrich. For the production of the master for PDMS microchip, silicon wafer (Siltron Inc., Korea), SU-8 (negative photoresist, Microchem Corp., Newton, MA, USA), and PDMS (Optrontec Inc., Korea) were used.

PCR product preparation. PCR reagents ( $50 \mathrm{mM} \mathrm{KCl}, 4$ $\mathrm{mM} \mathrm{MgCl}, 0.5 \mathrm{mM}$ dNTPs, $5 \mathrm{mM}$ Tris- $\mathrm{HCl}$, and $1 \mathrm{U}$ Taq polymerase) were obtained from Takara Bio Inc., Japan. MJ Research Thermal Cycle PCR (Waltham, USA) was used with two primers (5'-TCC AGA ATC TGT TCC AGA GCG TGC-3'(left primer) and 5'-GCT GTG AAG GTT GCT GTT CCT CAT-3'(right primer)) for amplification of CAG repeat region of $\mathrm{Xq11}-12$ exon 1 . PCR was performed by denaturation $\left(95^{\circ} \mathrm{C}, 40 \mathrm{~s}\right)$, annealing $\left(67^{\circ} \mathrm{C}, 40 \mathrm{~s}\right)$, and extension $(72$ 'C, 2 min) for 35 cycles.

Fabrication of microchip. A negative photoresist, SU-8 was spin coated at $5000 \mathrm{rpm}$ for $40 \mathrm{~s}$ on top of silicon wafer. After it was dried for 10 min, chrome mask was laid on silicon wafer and exposed at 365 nm. PDMS oligomer and curing agent $(10 ; 1)$ were mixed and the resulting bubbles were eliminated in desiccator. Then, PLMS was poured on the master and dried at $75^{\circ} \mathrm{C}$ for 2 hrs. For the formation of the microchannel, another PDMS layer was oxidized for 10 
min by Tesla coil (BD-10A, Electrotechnique Production, Inc., Chicago, IL, USA) and bound with PDMS having engraved channel pattern on it. Total channel length was 45 $\mathrm{mm}$ with the separation length of $35 \mathrm{~mm}$. The width and the depth for the channel were $80 \mathrm{~mm}$ and $50 \mathrm{~mm}$, respectively, with the channel length of $80 \mathrm{~mm}$ for double-T region.

DNA separation by PDMS microchip. PDMS microchip was cleaned with DI $\mathrm{H}_{2} \mathrm{O}, 0.10 \mathrm{M} \mathrm{HCl}, 0.10 \mathrm{M} \mathrm{NaOH}, 1 \mathrm{X}$ TBE for $5 \mathrm{~min}$, respectively, prior to injection of $1.2 \% \mathrm{PEO}$ containing of $3 \mu \mathrm{g} / \mathrm{mL}$ of $\mathrm{EB}$ to the separation channel. $\mathrm{PEO}$ was used as both dynamic coating material and sieving matrix for DNA separation. PEO was filled in the separation channel by the syringe pump for $10 \mathrm{~min}$, then stabilized for additional $10 \mathrm{~min}$.

DBMA-100 (Digital Bio Technology, Korea) equipped with DPSS laser $(532 \mathrm{~nm}, 10 \mathrm{~mW})$ and DBHV-100 high voltage supplier was used for separation and detection of DNA sample. A $3 \mu$ L of $50 \mathrm{ng} / \mathrm{nL} \Phi X 174 \mathrm{RF}$ DNA/Hae III and $3 \mu \mathrm{L}$ of $130 \mathrm{ng} / \mu \mathrm{L} 100 \mathrm{bp}$ DNA ladder were placed in reservoir 2. Then, DNA sample was injected by the pinched injection mode; step 1 , the reservoir 2 at $0 \mathrm{~V}$, the reservoir 3 at $600 \mathrm{~V}$, the reservoir 1 and 4 at floating for 40 s, step 2 , reservoir 1 at $0 \mathrm{~V}$, the reservoir 4 at $700 \mathrm{~V}$, the reservoir 2 and 3 at $200 \mathrm{~V}$ for DNA separation.

Statistical analysis. The size data from the control and the patients measured by PDMS microchip gel electrophoresis was then analyzed by multivariate analysis. Statistical significance between two groups was determined by Statistical Package for the Social Science (SPSS) with the independent sample t-test for the $\mathrm{CAG}$ repeat number.

$$
\begin{gathered}
t=\frac{\left(\bar{X}_{1}-\bar{X}_{2}\right)-D_{0}}{\sqrt{S_{P}^{2}\left(1 / n_{1}+1 / n_{2}\right)}} \\
S_{P}^{2}=\frac{\sum_{i=1}^{n_{1}}\left(X_{i}-\bar{X}_{1}\right)^{2}+\sum_{i=1}^{n_{2}}\left(X_{i}-\bar{X}_{2}\right)^{2}}{n_{1}+n_{2}-2}
\end{gathered}
$$

In equation (1), $\bar{X}_{1}$ represents the average of the control and $\bar{X}_{2}$ represents the average of the patients. $D_{0}$ is the assumed difference for two averages and generally 0 . In equation (2), $S_{P}^{2}$ means pooled variance. When $\mathrm{P}^{\mathrm{a}}$ value calculated by $\mathrm{t}-$ test is less than 0.05 , two groups are assigned to be statistically significant.

Acknowledgements. This study was supported by a grant of the Korea Health 21 R\&D Project, Ministry of Health \& Welfare, Republic of Korea. (A05-0503-A20718-05N1$0(010 \mathrm{~A})$.

\section{References}

I. Campzano, V.; Montermini, L.; Molto, M. D.; Pianese, L.; Cosssee, M.; Cavalcant, F. Science 1996, 27/, 1423.

2. Huntington's Disease Collaborative Research Group Cell 1993, 72,971 .

3. Nagafuchi, S.; Yanagisawa, H.; Salo, K.; Shirayama, T.; Ohsaki, E.; Bundo, M.; Takeda, T.; Tadokora, K.; Kondo, I.; Murayama, N.; Tanaka, Y.; Kikushima, H.; Umino, K.; Kurosawa, H.; Furukawa, T.; Nihei, K.; Inoue, T.; Sano, A.; Komure, O.; Takahashi, M.; Yoshizawa, T.; Kanazawa, I.; Yamada, M. Naftre Genetics 1994, 6, 1418 .

4. Orr, H. T.; Chung, M.-y.; Banfi, S.; Kwiatkowski, T. J., Jr.; Servadio, A.; Beaudet, A. L.; McCall, A. E.; Duvick, L. A.; Ranum, L. P. W.; Zoghbi, H. Y. Nature Gentet 1993, 4, 221.

5. La, S. A. R.; Wilson, E. M.; Lubahn, D. B.; Harding, A. E.; Fischbeck, K. H. Nature 1993, 352, 77.

6. Andrew, S. E.; Goldberg, Y. P.; Hayden, M. R. Hum, Mol. Genet. $1997,6,2005$.

7. Yong, E. L.; Loy, C. J.; Sim, K. S. Hthan Reproduction Update $2003,9,1$.

8. Ken-Ichiro, Y.; Masataka, Y.; Kouji, C.; Mikihiko, H.; Satoshi, K. Lrolog: 1999, 54

9. Jesse, M. H.; Andrew, B. C.; Mathieu, L.; Gail, V. W,; Peter, J. D. Journal of Nenroscience Methods 2005, 11, 144 .

10. Proceedings of MTAS Sympositm 2000 van den Berg, A.; Olthuis, W; Berveld, P., Eds.; Kluwer Academic Publishers: Dordrecht, The Netherlands. 2000.

11. Becker, H.; Gartner, C. Phssikalische Blatter 1999, 55, 51.

12. Effenhauser, C. S.; Paulus, A.; Manz, A.; Widmer, H. M. Anal. Chem. 1994, 66, 2949.

13. Xu, F.; Jabasini, M.; Zhu, B.; Ying, L.; Cui, X.; Arai, A.; Bada, Y. J. Chronatogr A 2004, /47/ /43, 1051 .

14. Jang, S. M.; Cho, K. C.; Chae, J. S.; Kang, S. H. Bull. Korean Chem. Soc. 2004, 25, 757.

15. Jeong, S. J.; Park, S. K.; Chang, J. K.; Kang, S. H. Bull. Korean Chem. Soc. 2005, 26,979.

16. Handbook of Capillary Electrophoresis; Landers, J. P., Ed.; CRC Press: Boca Raption, FL, 1996.

17. Liu, Y.; Ganser, D.; Schneider, A.; Liu, R.; Grodzinski, P.; Kroutchinina N. Anal. Chent. 2001, 4196, 73.

18. Manz, A.; Harrison, D. J.; Verpoorte, E. M. J.; Fetlinger, J. C.; Paulus, A.; Ludi, H.; Widmer, H. M. J. Chromatogr: 1992, 593, 253.

19. Harrison, D. J.; Manz, A.; Fan, Z.; Ludi, H.; Widner, H. M. Anal. Chem. 1992, 64, 1926.

20. Holger, B.; Laurie, E. L. Talanta 2002, 267, 56.

21. Clarson, S. J.; Semlyen, J. A. Siloxane Polymers; Prentice-Hall: Englewood Cliffs, NJ, 1993.

22. Dow Coming Corp., Midland, MI.

23. Soper, S. A.; Ford, S. M.; Qi, S.; McCarley, R. L.; Kelly, K.; Murphy, M. C. Anal. Chen. 2000, 72, A-Pages.

24. Deng. T.; Wu, H.; Brittain, S. T.; Whitesides, G. M. Anal. Chent. 2000. 72.3176 .

25. Jennifer, L. H.; Donald, H. A.; Xu, J.-F.; Edward Highsmith, W. J. Electrophoresis 2004, 25, 1852 .

26. Rajpert-De Meyts, E.; Leffers, H.; Petersen, J. H.; Andersen, A. G.; Carlsen, E.; Jorgensen, N.; Skakkebaek, N. E. Lafket. 2002. $350,44$.

27. Mifusd, A.; Sim, C. K.; Boettger-Tong. H.; Moreira, S.; Lamb, D. J.; Lipshulı, L. I.; Yong, E. L. Fertil. Steril. 2001, 75, 275. 